\title{
The Role of Visuals in the Communication Process
}

\author{
ALEXANDER KHORIN \\ Lomonosov Moscow State University, GSP-1, Leninskie Gory, Moscow, 119991, Russia \\ Email:Khorin_alex4@mail.ru
}

EKATERINA VORONOVA

Moscow State Institute of International Relations (MGIM0 University), Prospect Vernadskogo 76, Moscow, 119454, Russia

Email: kafstat@list.ru

\begin{abstract}
Information flows, without which it is impossible to imagine a modern society and its cultural environment, penetrate into all spheres of an individual's life thanks to digital technologies. As a result, social processes experience drastic changes in the ways and forms of cognition and transformation of the surrounding reality, as well as in the processes of formation and representation of the individual in society. As a result of the development of digital information technologies, significant changes have occurred in the living space and the perception of time by a person of the 21 st century. The Internet has formed its own unique information space, with its own special social and technological characteristics. A virtual network is a space for global communication and high-speed data dissemination, as well as an environment for people's interaction that is not limited by the barriers of traditional mass media. All this has created a new type of culture - the culture of virtual reality, since our reality consists mainly of everyday virtual experiences.
\end{abstract}

Keywords: visuality, visual communication, communication process

\section{INTRODUCTION}

Communication is the basic mechanism for integrating a person with social, natural and cultural spheres (Luhmann 2015). Currently, under the influence of information and communication processes, society is experiencing crisis moments that are particularly noticeable in the financial, social, political and cultural areas of life, which implies a radical re-evaluation and reinterpretation of the phenomena of modern culture (Mitchell 1995). The sphere of sociocultural, of which visual culture is a part, presupposes sociocultural communication (Spanbroek 2010). It goes far beyond aesthetic and artistic interaction and implies active interaction in the socio-cultural space of public life (Strickfaden 2010). In the context of the predominance of visual culture in modern society, researchers are increasingly paying attention to the study of visual communication (Hey 2003). 
Today, visual communication occupies a particularly important position: figurative information is universal for all languages and nationalities, does not require translation, and is easily perceived and remembered (Kalpokas 2015). We use a visual channel to convey a specific message that does not require context: increasingly, we use images rather than text to convey information (Tarte 2010). Today, visuality is a convergence of the verbal and the visible. It becomes the primary way of translating meanings, traditions and social norms, and constructs modern reality using visual mechanisms (Kindi 2017). The study of visual communication raises questions of interpretation and understanding, multiplicity of meanings, representation and self-representation, the problem of mediatization and virtualization of everyday life, the construction of new channels of communication and information transfer, and the formation of social ties in general (Ford 2004).

The object of the research is communication in the risk society.

The goal of the research is a philosophical understanding of the impact of visual communication on the transformation of the socio-cultural environment.

The methods of the research that were used to solve the tasks in the work are a system of several formative approaches. The methodological and theoretical basis of the research is the work of foreign and domestic scientists in the field of social philosophy, philosophy of culture, cultural studies and media philosophy.

\section{VISUALNESS AND VISUAL CULTURE}

When investigating the visual paradigm, first of all, it is necessary to conduct a categorical analysis of the concepts and phenomena under consideration. The concepts of visual culture and visual communication are of fundamental methodological importance for our work. First of all, the visual type of communication is part of the paradigm of visualness and visual culture in general. Visual culture combines the cultural, social and cognitive functions of visual environments and practices - from classical painting to photography and cinema, from architecture to advertising and products of a limitless virtual space. It focuses on the transformations taking place in modern culture and society, and works in this area are a theoretical understanding of this development. It includes a description, registration of modern processes in culture and theoretical analysis of the specifics of visual practices, as well as their interaction with social phenomena and their impact on society and its individuals. Thus, visual culture is at the intersection of several areas - art theory, media, psychoanalysis, semiotics, philosophy and discursive practices of cultural studies.

The formation of the paradigm of visualness and visual culture as such is associated with a 'visual turn' in the Humanities. From this point on, art loses its status as an elitist, ceases to be a privileged form of visuals, just as art criticism becomes the dominant theoretical discourse. Many researchers have recognized the onset of the 'visual turn' - the triumph of visualness, which has become a way of being culture and society, a representation and a way of constructing everyday life. Today, the image forms and fills our everyday world with meanings, actually filling the entire space of everyday life. From now on, the world of culture is ruled by visual media.

The widespread domination of the visual paradigm is also evidenced by transformations in other scientific fields, as W. J. T. Mitchell writes: 'the New world of visual culture, the formation of which is persistently repeated by sociologists, art critics and cultural scientists, influences and formats not only the mass consciousness, but also science, generating new scientific directions, theories and practices' (Mitchell 1995: 540). 
One of the most influential researchers of visual art, Mitchell, noted the revolutionary changes in society - the multiple increase in interest and the overwhelming influence of visual practices. Accordingly, this has led to an increase in the number of studies of mass communications and mass culture, the emergence of social and philosophical concepts that study mass communication, including visual communication (Mitchell 1995: 543).

Thanks to this state of affairs, visualness has ceased to be something elitist and secondary to the basic, everyday culture, it has become itself everyday, as N. Mirzoeff wrote about it (Mirzoeff 1999: 7). Visual culture is a new level of understanding of socio-cultural and philosophical issues, the transformation of abstract concepts into more substantive ones.

As part of this study, we consider the processes of visualization and virtualization in conjunction, as the world is increasingly digitized. Virtual Internet technologies capture all areas of life: manufacturing and medicine, money relations and politics, service and media, creativity and art, education and travel, and, of course, the individual's personal life. The Internet interface itself is an image. The network gradually embraces culture and social relationships that are transformed by new conditions. To some extent, the image can be autonomous from web technologies - for example, in the print press or when creating a picture, but if you delve into their relationship, it becomes obvious that searching for news, writing text, creating paints and buying a canvas can hardly be done without computer technology today. We buy things, learn information and communicate through Internet resources, and consumption, communication and information are the main processes in the modern world. Thus, we inextricably link the concepts of 'virtualization' and 'visualization' and adhere to the position that the consideration of one phenomenon separately from another in the light of today's realities will not be complete and haphazard.

In the age of virtuality, the image (or in other words, the message encoded in the image) broadcast by the mass media defines reality. Modern society is a space of excessive visual content. Deciphering this position, we explain that everything around a person is somehow visible, so visible that it becomes excessive. The introduction of media technologies into the social reality of an individual generates excessive visual content and is accompanied by a number of social and personal risks that require philosophical reflection. The socio-philosophical analysis of visualness and its role in the communication process allows us to consider it as a social construct of interaction between society, the individual and the image.

\section{TYPE AND FORMS OF VISUAL COMMUNICATION}

Visual communication as a form of information technology plays an important role in shaping human reality. In an 'idealized', flawless, virtual environment, a person is faced with simulacra-images and signs of things, not the things themselves. The purpose of transmitting information using visualized forms - photos and videos, multimedia illustrations, and graphic design - is to be efficient and fast. The dynamic nature of visuals was the result of the merging of technology and visual forms of expression: photography, cinema, television and, ultimately, the Internet. In this regard, rapidly changing behavioural codes of a person, his daily life, the relationship with other individuals. The perspective of social virtualization is to transform interpersonal relationships into relationships between images. Thus, a different interpretation of social changes appears, in which the distinction between the old and new types of social organization is established using the dichotomy: 'real-virtual'.

People form their own opinions and make decisions based on the data they receive from the media. Although they process the received information individually, the content 
of information messages is predetermined and structured in such a way that the subjects are absolutely passive in choosing and only process the data stream set from the outside. Visuals 'capture' everyday life, it has an impact on a person's living space, changes the nature of their perception of the world around them and patterns of behaviour and communication with individuals. Social movements are increasingly the expression of an opinion in a world of collective images and representations, just as terrorism and the fight against it often use images of fear, intimidation and destruction, rather than actual physical force (Fig. 1).

An image is a powerful communication channel, and even in its most primitive form, it is potentially communicative, since it is a coded message that constantly needs to be interpreted by the recipient-viewer. An image is a condition for communication not only between a person and an object, but also between a person and another person using a visual intermediary. Any object or subject that falls at least for a moment in the field of human vision, provokes an act of communication and is automatically included in the area of visual space, designed by the eye. Due to the visibility of the surrounding space and the need for its perception and decoding, it becomes completely communicative and endowed with multiple meanings, which the individual constantly operates in the process of his life.

J. Lacan wrote: 'what is visible does not reveal, but hides', thereby giving a socio-political tone to the visual and giving its space the properties of a social myth (Lacan 1965-1966). If we have a screen with an image in front of us, it means that what we see is different from what is 'behind' it, that is, the explicit meaning of the message. So the screen acts as an intermediary between the viewer and the object, and as a barrier that hides the truth, as V. Benjamin wrote (Benjamin 1996). According to Lacan, the screen acts as a metaphor for the social reality of a person, hiding the shortcomings of everyday life and transforming the true state of affairs; it is a distancing and alienation of a person from the world around him. Today, however, visualness is much more than just an image. It is necessary for the viewer to feel what he has seen; this is achieved through modern computer technologies when a person is literally immersed in the depicted reality, experiencing the maximum impact of the image. Examples are, of course, 3-D movies, 3-D photo exhibitions, TV ads with an 'ultra-sensitive' screen and a superreal image, as well as interactive exhibitions of modern art (for example, actionism, happening, cyber art, op art, kinetic art) when a person can not only touch or observe, but also independently start the process of reproducing an art object, give an impulse to the beginning of the presentation by pressing a lever or a button. In the case of art, this helps a person not

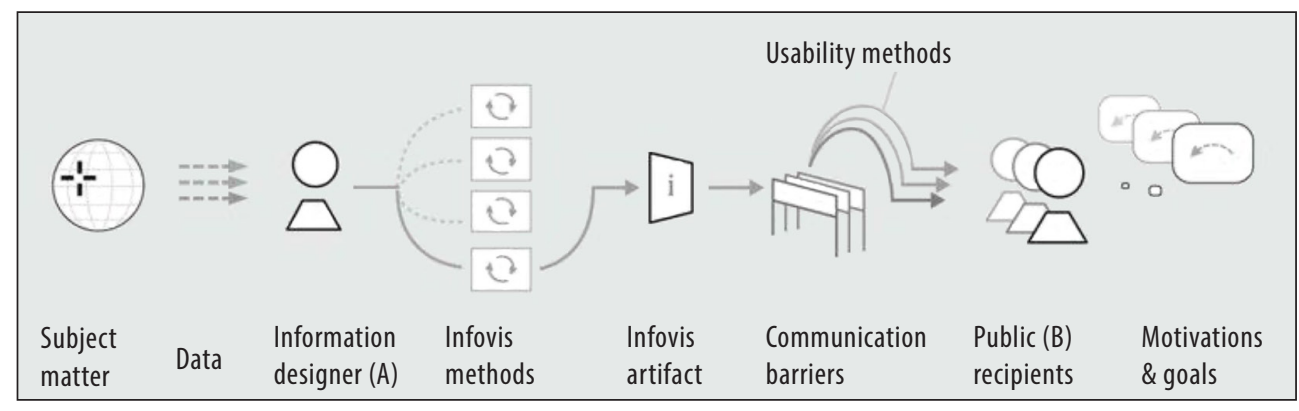

Fig. 1. Visual communication model

Source: author's research. 
only to feel and understand the concept more strongly, but also to feel like a co-author and co-creator; in the case of advertising, this technique encourages the viewer to identify with the advertised object and gives rise to a sense of need to buy (Fig. 2).

The written text and the book gradually lost their sacred meaning with the invention of printing, and the image lost its spirituality and sanctity with the invention of photography. Today, in an era of total virtualization and moving a significant part of an individual's life to the Internet, an image actually replaces a word that fades into the background and ceases to be so indispensable, and is transformed into a universal unit of 'language' - a modern visual language of communication. There is a kind of synthesis of speech and image - a written text in the Internet space, supplemented by animated pictures depicting various actions, emotions and events. Of course, people still communicate using oral speech; however, today the area of communication is shifting to the virtual space of the network, and this is a fact that cannot be denied. We do not give up speaking, but visualness dominates many areas of our life: when reading a text, we rely on illustrations, making a report, we confirm it with graphs and diagrams, sharing personal stories, showing photos as proof of words.

Spreading this idea, we can come to the conclusion that reading and understanding the text gives way to the consumption of the image due to the powerfully developed consumer ability of modern society. An image is a 'packaged' message, as a product, that is most convenient for a person's perception, containing a thought, an idea that has been raised to the surface - demonstrated. Convenience of perception is a key characteristic of a mass society, a member of which needs 'everything at once'.

Explicating the idea of society's theatricality in the media sphere, it can be argued that media technologies and their products constantly increase the effectiveness of images' impact

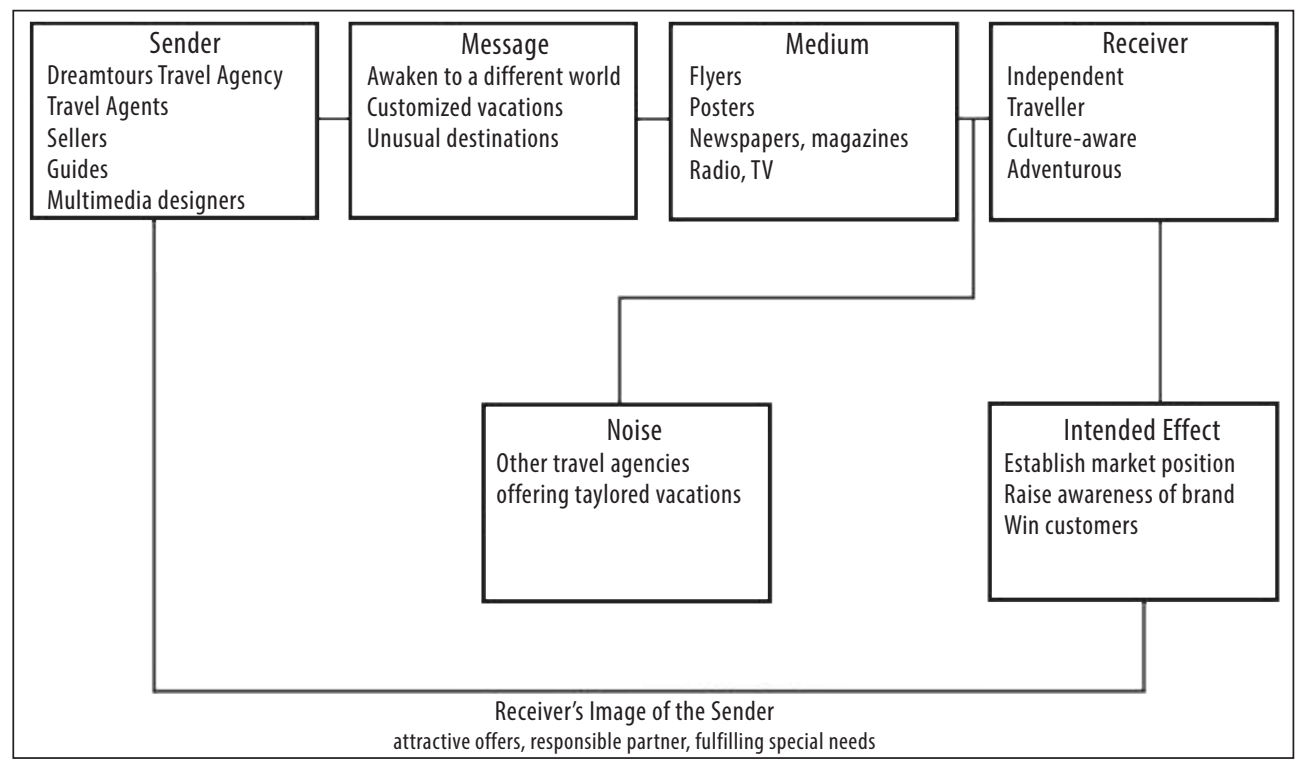

Fig. 2. Communication model with visual identity

Source: author's research. 
on the consumer's consciousness: colourful packaging and bright wrappers of products, flashy inscriptions and slogans, huge posters and banners hanging along streets and roads. The visual nature of the mass media, despite the deceptive diversity of its forms, leads to the unification of thinking. The processed information contained in the media image is presented in a simplified form, which actually eliminates the need for independent analysis, synthesis and criticism of data. Roland Barth writes: 'His [common sense] task is to establish the simplest equality between the visible and the existent, maintaining an image of the world where there are no intermediate links, no transitions, no development'. But in the conditions of simplified logical connections and simplification of mental activity, the individual develops an automatic non-reflexive identification of forms of appearance and content, whether it is a person or a product.

\section{CONCLUSIONS}

The modern system of communication tools has become so flexible that it adapts to a specific message and a specific audience. Information in the form of text or digital code, i.e. messages in a symbolic form that can express the personal attitude of its author to the world around him, has become a tool in the process of creating new realities. Reality no longer shapes the content of the message, the situation has changed to the opposite: the message defines reality. Communication became the basis for creating a media space that initiates the production, processing and translation of meanings. Cyberspace endlessly generates hypertexts and forms signs and simulations, combining many different visual, interactive and auditory codes. The person is immersed in the symbolic reality of virtual images and perceives the objective world as a game environment: reality loses its status. With the development of telecommunications technologies, the nature of virtuality also changes: it is a special space that specializes in the virtualization of all objects. Thus, virtuality forms a completely new level of symbolic existence of society and culture. Constructed indirectly by technology, rather than directly by man, a media space that generates images, meanings and a system of symbols of any complexity, as well as having a huge communication potential, is able to construct hyperreal worlds, communities and culture.

We observe an increase in the role of the subjective factor in society and an increase in the need for constant self-presentation of the individual in order to indicate his presence and actualize the activity. Accordingly, the need for self-identification increases in the context of the erosion of rigid social and natural determinants and the total spread of pluralism of opinions. The created culture of the Internet community appears as a basis for constructing a new culture and includes an appropriate system of value orientations and norms, which include pluralism of opinions, dialogicality, imaginary freedom of speech and anonymity, independence, the presence and active expression of one's own opinion, the dynamics of communications, high activity of participants in the communication process and selectivity.

Philosophers, scientists, public figures, art critics and commentators talk about the corrupting influence of the mass media, the loss of traditional cultural values and morals, and the decline of the education system due to the decline of book-writing culture. However, it is impossible to say unequivocally that destructive socio-cultural phenomena are exclusively the result of the influence of modern technologies. The traditional aspect is not something permanent, since tradition is tied to a historical period of time. The older generation, brought up in different conditions, perceives media culture as something hostile and tries to resist it, first of all, by strengthening the administrative resource and the institution of education.

Received 5 February 2020

Accepted 7 September 2020 


\title{
References
}

1. Benjamin, V. 1996. 'A Work of Art in the Era of Its Technical Reproducibility', Selected Essays 14(2): 126-143.

2. Debord, G. 2016. 'Theses on Cultural Revolution', Moscow Art Magazine 79(12): 121-130.

3. Floridi, L. 2008. 'Trends in the Philosophy of Information', in Handbook of Philosophy of Science, eds. P. Adriaans and J. van Benthem. Amsterdam, London, North Holland: Elsevier, 113-132.

4. Ford, N. 2004. 'Modeling Cognitive Processes in Information Seeking: From Popper to Pask', Journal of the American Society for Information Science and Technology 55(4): 769-782.

5. Ford, N.; Wilson, T. D.; Foster, A.; Ellis, D.; Spink, A. 2002. 'Information Seeking and Mediated Searching. Part 4. Cognitive Styles in Information Seeking', Journal of the American Society for Information Science and Technology 53(3): 728-735.

6. Hey, T.; Trefethen, A. 2003. 'The Data Deluge: An e-Science Perspective', in Grid Computing: Making the Global Infrastructure a Reality. John Wiley and Sons, 809-824.

7. Kalpokas, D. E. 2015. 'Perceptual Experience and Seeing-as', Nordic Wittgenstein Review 4(1): 123-144.

8. Kindi, V. 2017. 'Wittgenstein and Philosophy of Science', in A Companion to Wittgenstein, eds. H.-J. Glock and J. Hyman. John Wiley and Sons, 587-603.

9. Lacan, J. 1965. 'The Object of Psychoanalysis 1965-1966', Journal of Psychoanalysis and Personality Intentions 22(2): 113-124.

10. Luhmann, N. 2015. 'The Reality of the Mass Media', Moscow Art Magazine 78(4): 30.

11. Mirzoeff, N. 1999. An Introduction to Visual Culture. New York: Routledge.

12. Mitchell, W. J. T. 1995. 'Interdisciplinarity and Visual Culture', Art Bulletin 76(4): 540-544.

13. Spanbroek, N. 2010. 'Strategic Teaching: Student Learning Through Working the Process', World Journal of Learning 29(2): 111-120.

14. Strickfaden, M.; Heylighen, A. 2010. 'Cultural Capital: A Thesaurus for Teaching Design', Journal of Philosophy and Culture 29(2): 121-133.

15. Tarte, S.; Bowman, A.; Brady, M.; Terras, M. 2010. 'Image Capture and Processing for Enhancing the Legibility of Incised Texts', in Eikonopoiia: Symposium on Digital Imaging of Ancient Textual Heritage: Technological Challenges and Solutions, ed. M. Holappa. University of Helsinki, 138-149.

\section{ALEXANDER KHORIN, EKATERINA VORONOVA}

\section{Vizualumo vaidmuo komunikacijos procese}

\begin{abstract}
Santrauka
Informacijos srautai, be kurių neịmanoma ịsivaizduoti modernią visuomenę ir jos kultūrinę aplinką, skaitmeninemis technologijomis persmelkia visas individo gyvenimo sritis. Dèl to socialiniai procesai patiria drastiškus supančios tikrovès pažinimo ir transformavimo būdų bei formų pokyčius, ne mažiau kinta individo formavimas ir reprezentavimas visuomenejje. Tobulëjant skaitmeninèms informacinèms technologijoms reikšmingi pokyčiai ištiko XXI a. asmens gyvenamąją erdvę ir laiko percepciją. Internetas suformavo savą unikalią informacinę erdvę, pasižyminčią specifinemis socialinėmis ir technologinėmis ypatybėmis. Virtualus tinklas yra erdvé globaliai komunikacijai ir itin greitam duomenų perdavimui, taip pat - aplinka žmonių interakcijai, nevaržomai tradicinès žiniasklaidos. Visa tai sukūrè naują kultūros tipą - virtualios realybės kultūrą, nes mūsų realybę iš esmès sudaro kasdienès virtualios patirtys.
\end{abstract}

Raktažodžiai: vizualumas, vizualinè komunikacija, komunikacijos procesas 